\title{
Fibrous Agricultural Biomass as a Potential Source for Bioconversion to Vanillic Acid
}

\author{
Pei-Ling Tang, 1 Osman Hassan, ${ }^{1}$ Jamaliah Md-Jahim, ${ }^{2}$ \\ Wan Aida Wan Mustapha, ${ }^{1}$ and Mohamad Yusof Maskat ${ }^{1}$ \\ ${ }^{1}$ School of Chemical Sciences and Food Technology, Faculty of Science and Technology, Universiti Kebangsaan Malaysia, \\ 43600 Bangi, Selangor, Malaysia \\ ${ }^{2}$ Department of Chemical and Process Engineering, Faculty of Engineering and Built Environment, Universiti Kebangsaan Malaysia, \\ 43600 Bangi, Selangor, Malaysia \\ Correspondence should be addressed to Osman Hassan; osmanhassan@yahoo.com
}

Received 16 June 2014; Revised 4 September 2014; Accepted 4 September 2014; Published 15 September 2014

Academic Editor: Yulin Deng

Copyright (C) 2014 Pei-Ling Tang et al. This is an open access article distributed under the Creative Commons Attribution License, which permits unrestricted use, distribution, and reproduction in any medium, provided the original work is properly cited.

\begin{abstract}
This study was conducted to assess the potential of six fibrous agricultural residues, namely, oil palm empty fruit bunch fiber (OPEFBF), coconut coir fiber (CCF), pineapple peel (PP), pineapple crown leaves (PCL), kenaf bast fiber (KBF), and kenaf core fiber (KCF), as a source of ferulic acid and phenolic compounds for bioconversion into vanillic acid. The raw samples were pretreated with organosolv ( $\mathrm{NaOH}$-glycerol) and alkaline treatment $(\mathrm{NaOH})$, to produce phenol-rich black liquor. The finding showed that the highest amount of phenolic compounds and ferulic acid was produced from CCF and PP, respectively. This study also found that organosolv treatment was the superior method for phenolic compound extraction, whereas alkaline treatment was the selective method for lignin extraction. Vanillic acid production by Aspergillus niger I-1472 was only observed when the fermentation broth was fed with liquors from PP and PCL, possibly due to the higher levels of ferulic acid in those samples.
\end{abstract}

\section{Introduction}

Lignocellulose feedstock has been recognized as the most promising material for renewable energy and biobased products. It is the most abundant renewable resource on earth, with a yearly production of approximately $200 \times 10^{9}$ tons, and only $3 \%$ is used for nonfood industries such as the paper and pulp industries. In Malaysia, oil palm industry is the most important income generator. However, it also generates the largest portion of the total lignocellulosic waste in the country. Apart from oil palm, the agricultural sector also produces significant amount of lignocellulose waste from rubber, paddy straw, rice husk, banana stem, sugarcane bagasse, coconut husk, and pineapple residues [1].

Utilization of lignocellulosic polymer from crop residues will reduce the environmental impact and add extra revenue to the agriculture sector after conversion into biofuel and biorefinery [2]. To enhance the biomass utilization, various pretreatment methods on oil palm fibers have been investigated to produce black liquor and cellulosic fibers for enhanced sugar production $[3,4]$. Black liquor is a complex aqueous solution comprised of organic materials such as lignin fragments, polysaccharide fragments, lignindegradation products, polysaccharide-degradation products, low molecular mass resinous compounds, and inorganic compounds, mainly soluble salt ions [5]. Alkaline treatment is the most common technique to release phenolic acids from the lignin-carbohydrate complex $[6,7]$. Among the phenolic compounds identified from lignin extraction from lignocellulose, ferulic acid has gained the greatest interest, as US and European legislation permitted the labeling of biotechnologically produced vanillin from ferulic acid as a natural product. Ferulic acid has been shown to be the precursor of vanillin production through a fermentation process $[7,8]$. Vanillin is the most important and widely used flavor in the food industry [9]. Structurally, ferulic acid functions as a cross-linking bridge between lignin and polysaccharides, particularly in hemicellulose, via ester and ether bonds, forming lignin/phenolic-carbohydrates complexes in lignocellulosic residues $[6,10]$. Thus, the liberation of ferulic acid is 
dependent on the cleavage of ester and ether bonds between lignin and carbohydrate [11]. Therefore, for the production of natural vanillin, the potential of an agricultural residue as a source of ferulic acid is related to the content and structure of hemicellulose and lignin.

Filamentous fungi, especially white-rot basidiomycetes, have been reported to metabolize ferulic acid into vanillic acid and vanillin. However, this reaction always yielded a small quantity of vanillin due to the formation of methoxyhydroquinone and vanillyl alcohol. Therefore, the two-step bioconversion of ferulic acid into vanillin was proposed, whereby Aspergillus niger will convert ferulic acid into vanillic acid, which will then be transformed into vanillin by Pycnoporus cinnabarinus [9]. Vanillic acid can be used as the precursor for vanilla production as well as other important industrial derivatives, such as 5-nitrovanillic acid and 5-aminovanillic acid, for antibacterial applications [12].

In this study, the fibrous biomass from pineapple (Ananas comosus var Morris), oil palm (Elaeis guineensis), coconut (Cocos nucifera), and kenaf (Hibiscus cannabinus) was used as the raw materials for the production of phenolic compounds, particularly ferulic acid. The composition of black liquors produced using two different methods, alkaline treatment (sodium hydroxide) and alkaline aqueous organosolv treatment (aqueous alkaline glycerol), was studied. The suitability of these methods was compared based on the total phenolic compounds, the extent of delignification, and ferulic acid content derived. The fermentability of the resultant black liquor was tested using Aspergillus niger I-1472. The potential of agricultural residues as a source of ferulic acid was evaluated based on the vanillic acid yield from A. niger fermentation.

\section{Materials and Methods}

\subsection{Materials}

2.1.1. Raw Materials. Fresh, ripe pineapple was purchased from the local market in Kajang, Selangor. The fibrous residues of pineapple were the peel (PP) and crown leaves (PCL). Fresh PP and PCL were oven-dried at $105^{\circ} \mathrm{C}$ until a constant weight was reached (moisture $\sim 5 \%$ ). Oil palm empty fruit bunch fiber (EFBF) was obtained from the Sime Darby Plantation Ltd. Fresh EFBF was washed and sun-dried until the moisture content was $\sim 10-11 \%$. Coconut coir fiber (CCF) was obtained from freshly plucked coconut at $\mathrm{Kg}$. Sungai Tangkas, Selangor. The fresh CCF was sun-dried until the moisture content reached $\sim 9-10 \%$. Kenaf bast fiber (KBF) and kenaf core fiber (KCF) were obtained from the Malaysian Kenaf and Tobacco Board. Kenaf was crushed and separated to obtain KBF and KCF. All samples were cut into sizes of $5-8 \mathrm{~cm}$. All six samples were stored in sealed plastic bags at $\sim 4^{\circ} \mathrm{C}$ until used for experiments. Compositional analyses of all samples were determined according to a modified NREL (National Renewable Energy Laboratory) standard method (described in Section 2.2.1).

2.1.2. Chemicals. The chemicals used included anhydrous glycerol (Systerm, Malaysia); Folin-Ciocalteu reagent, ferulic acid, vanillic acid, malt extract agar, D-(+)-maltose monohydrate, diammonium tartrate, and yeast extract (Sigma Aldrich, USA); and HPLC grade methanol, sodium hydroxide, potato dextrose agar, magnesium sulfate, dipotassium hydrogen phosphate, and calcium chloride (Merck, Germany). All other chemicals were obtained from commercial sources and were of analytical grade.

2.1.3. Fungal Strain. Aspergillus niger I-1472 was purchased from the Collection Nationale de Culture de Microorganismes (CNCM), Institut Pasteur (Paris, France). The strain was maintained on malt extract agar (contained $20 \mathrm{~g} \mathrm{~L}^{-1}$ malt extract and $15 \mathrm{~g} \mathrm{~L}^{-1}$ agar) at $-40^{\circ} \mathrm{C}$.

\subsection{Methods}

2.2.1. Compositional Analysis. Compositional analysis of the biomasses examined moisture, ash, total extractive, total carbohydrate, and total lignin content [13-15]. The moisture content was determined by heating the samples in an oven at $105^{\circ} \mathrm{C}$ until a constant weight was achieved, whereas the ash content analysis was conducted using a furnace at $575^{\circ} \mathrm{C}$ for 18 hours. The total extractive content of the biomass was determined by refluxing the samples with distilled water for 12 hours, followed with $95 \%$ ethanol for 12 hours in a Soxhlet extractor. Extractive-free samples were hydrolyzed with $72 \%$ sulfuric acid at $30^{\circ} \mathrm{C}$ for 1 hour, followed by hydrolysis with $4 \%$ sulfuric acid at $120^{\circ} \mathrm{C}$ for 1 hour. Total carbohydrate content was determined based on total sugar content in the hydrolysate. The total sugar content was quantified using high performance liquid chromatography (HPLC) equipped with an evaporative light scattering detector (ELSD) (Waters, Milford, USA). The HPLC column used was a TSKgel NH2$100,3 \mu \mathrm{m}$ (TOSOH, Japan), and the samples were eluted with a mobile phase comprised of HPLC grade acetonitrile and deionized water (ratio $80: 20$ ) at a flow rate of $1 \mathrm{~mL} \mathrm{~min}^{-1}$. The mobile phase was filtered with a $47 \mathrm{~mm}$ nylon membrane with a pore size of $0.45 \mu \mathrm{m}$ and degassed. All of the standards and samples were filtered through $0.22 \mu \mathrm{m}$ nylon membrane prior to analysis. The standards used for sugar qualitative and quantitative analysis were glucose, xylose, and cellobiose (Sigma Aldrich, USA). Sugar analysis was conducted with an injection volume of $20 \mu \mathrm{L}$, and data acquisition was performed with Breeze software (Waters, Milford, USA). Filtration of the hydrolysate in a vacuum resulted in the collection of the insoluble residue. The acid insoluble residue was regarded as acid insoluble lignin. Soluble lignin analysis was determined spectrophotometrically at $205 \mathrm{~nm}$ using a spectrophotometer (Thermo-Spectronic) with a quartz cuvette.

2.2.2. Preparation of Black Liquor. Black liquor was produced using alkaline and organosolv treatments on the biomass. Alkaline treatment was conducted using $250 \mathrm{~mL} 50 \mathrm{~g} \mathrm{~L}^{-1}$ sodium hydroxide, whereas organosolv treatment was conducted using a $250 \mathrm{~mL}$ mixture of $50 \mathrm{~g} \mathrm{~L}^{-1}$ sodium hydroxide and $1.217 \mathrm{~g} \mathrm{~mL}^{-1}$ aqueous glycerol at a ratio of $44: 56$. For PP, $\mathrm{PCL}$, and KCF, the treatments were conducted at $4 \%$ total 
solid, whereas, for EFBF, CCF, and KBF, treatments were conducted at $2 \%$ total solid. Lower solid loading (2\%) was chosen for the experiments on EFBF, CCF, and KBF because there were experimental limitations for high solid loading (4\%). The $2 \%$ and $4 \%$ solid loading were the maximum sample load in the current experiment setting for EFBF, CCF, and $\mathrm{KBF}$ and PP, PCL, and KCF, respectively. At such experiment setting, the treatment solvent was at the level of coverage just above the substrates. Treatment of these lignocellulosic biomasses was performed using a $500 \mathrm{~mL}$ Erlenmeyer flask at $120^{\circ} \mathrm{C}$ (autoclave) for 1 hour. After treatment, black liquor was separated from the treated biomasses by vacuum filtration. All experiments were performed in triplicate.

\subsubsection{Chemical Analysis}

(a) Total Soluble Lignin Analysis. The collected black liquor was diluted until the absorbance at $205 \mathrm{~nm}$ fell between 0.2 and 0.7 [16]. The absorbance of black liquor was determined using a UV-Vis spectrophotometer Thermo-Spectronic (Thermo Fisher Scientific Inc., Massachusetts) using a quartz cuvette. The amount of total soluble lignin in the black liquor from different biomass samples was calculated as follows:

$$
\begin{aligned}
& \text { Total soluble lignin }\left(\mathrm{mg} \mathrm{g}^{-1} \text { biomass; } d . b .\right) \\
& =\frac{\mathrm{abs}_{205 \mathrm{~nm}} \times \mathrm{DF} \times V_{\text {Total }}}{b \times a \times \mathrm{Wt}_{\text {sample }}}
\end{aligned}
$$

where $\mathrm{abs}_{205 \mathrm{~nm}}$ is the absorbance at wavelength $205 \mathrm{~nm}, \mathrm{DF}$ is the dilution factor, $V_{\text {Total }}$ is the total volume of hydrolysate, $b$ is the cell path length $(1 \mathrm{~cm}), a$ is the absorptivity $\left(110 \mathrm{mg} \mathrm{mL}^{-1}\right.$ $\mathrm{cm}^{-1}$ ), and $\mathrm{Wt}_{\text {sample }}$ is the sample weight (dry basis).

Previously reported studies showed that lignin measurements were conducted at a wavelength of $280 \mathrm{~nm}$ [17], but our own preliminary experiments using UV-Vis spectrum scanning on alkali Kraft lignin (Sigma Aldrich, USA) in the range of 200 to $350 \mathrm{~nm}$ showed that the maximum absorbance of lignin was at a wavelength between $205 \mathrm{~nm}$ and $280 \mathrm{~nm}$. The same UV-Vis spectrum scanning range was also performed on both furfural and hydroxymethylfurfural, which are the most common carbohydrate degradation products from black liquor. The results showed that both of these compounds possess a maximum absorbance at $280 \mathrm{~nm}$ (data not shown). To avoid interference from these carbohydrate-degraded compounds, soluble lignin measurements at $205 \mathrm{~nm}$ were assessed in this study.

(b) Ferulic Acid Analysis. The $\mathrm{pH}$ of the collected black liquor was adjusted to 2.0 using concentrated sulfuric acid. Soluble lignin was precipitated under acidic conditions [18]. The lignin precipitate was separated by centrifugation at $3500 \mathrm{rpm}(2000 \times \mathrm{g})$ for $5 \mathrm{~min}$. Subsequently, the supernatant was collected and neutralized to $\mathrm{pH}$ 5-6 using calcium carbonate powder prior to ferulic acid content analysis. This supernatant at pH 5-6 was also used as the feeding substrate during fermentation by $A$. niger.
The ferulic acid content analysis was performed by HPLC equipped with an ultraviolet detector at a wavelength of $280 \mathrm{~nm}$ (Waters, Milford, USA). A $250 \times 4.6 \mathrm{~mm}$ HPLC column Purospher STAR RP-18e (Merck, Germany) with a $5 \mu \mathrm{m}$ particle size was used, and the sample was eluted using $0.1 \%$ acetic acid (solvent $\mathrm{A}$ ) and methanol (solvent $\mathrm{B}$ ). The mobile phase gradient was $80: 20$ (A:B) from 0 to $24 \mathrm{~min}$, $60: 40(\mathrm{~A}: \mathrm{B})$ from 24 to $27 \mathrm{~min}, 20: 80$ (A:B) from 27 to $36 \mathrm{~min}$, and $80: 20(\mathrm{~A}: \mathrm{B})$ from 36 to $40 \mathrm{~min}$. The flow rate for analysis was fixed at $1 \mathrm{~mL} \mathrm{~min}^{-1}$. The mobile phase was filtered through a $47 \mathrm{~mm}$ nylon membrane with a pore size of $0.45 \mu \mathrm{m}$ and degassed. All of the standards and samples were filtered through a $0.22 \mu \mathrm{m}$ nylon membrane prior to analysis. Ferulic acid analysis was conducted with an injection volume of $10 \mu \mathrm{L}$, and data acquisition was performed with Breeze software (Waters, Milford, USA).

(c) Total Phenolic Compound and Total Nonferulate Phenolic Compound (NFPC) Analysis. The neutralized soluble ligninfree liquor was used for total phenolic compound analysis. Total phenolic compounds were determined using the FolinCiocalteu method [19]. Approximately $0.5 \mathrm{~mL} 0.2 \mathrm{~N}$ FolinCiocalteu was added to a $0.1 \mathrm{~mL}$ sample aliquot. After $5 \mathrm{~min}$

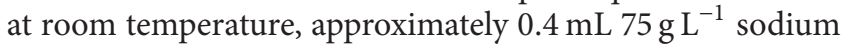
carbonate solution was added, and the mixture was brought to a volume of $5 \mathrm{~mL}$ using distilled water. The solution mixture was incubated at room temperature in the dark for 2 hours. The absorbance of the mixture was determined spectrophotometrically at a wavelength of $760 \mathrm{~nm}$ using a VERSAmax ELISA microplate reader equipped with SOFTmax Pro (Molecular Devices, USA) software. The total phenolic compounds in black liquor were quantified based on the constructed calibration curve using gallic acid as reference. The concentration of total phenolic compounds was expressed as milligrams of gallic acid equivalent per milliliters of liquor.

The total nonferulate phenolic compound (NFPC) content was defined as the total phenolic compounds present in the lignin-free liquor (excluding ferulic acid). Total NFPC was determined as gallic acid equivalents by subtracting the amount of ferulic acid from the total phenolic content. The amount of ferulic acid, as gallic acid equivalents, was determined by preparing a concentration series of ferulic acid and quantified spectrophotometrically based on the constructed calibration curve using gallic acid as a reference. A linear graph describing the relationship between actual ferulic acid content and the ferulic acid content as a gallic acid equivalent was constructed. The amount of ferulic acid present in liquor, which was determined using HPLC, was converted into unit milligram of gallic acid equivalent per milliliter of liquor using the constructed linear graph.

2.2.4. Fermentation. The fermentability of the lignin-free liquors from different agricultural residues was evaluated using Aspergillus niger I-1472. A. niger I-1472 was grown on malt extract agar $\left(20 \mathrm{~g} \mathrm{~L}^{-1}\right.$ malt extract and $15 \mathrm{~g} \mathrm{~L}^{-1}$ agar $)$ at $30^{\circ} \mathrm{C}$, and the spores were harvested after one week of growth. Approximately $1 \%$ of the spore suspension (spore concentration of $10^{6}-10^{7} \mathrm{cfu} \mathrm{mL}^{-1}$ ) was inoculated into $30 \mathrm{~mL}$ basal 
TABLE 1: Composition of six different biomasses (palm oil empty fruit bunch fiber, coconut coir, pineapple peel, pineapple crown leaves, kenaf bast fiber, and kenaf core fiber) in this study $(n=3 ; P<0.05)$.

\begin{tabular}{|c|c|c|c|c|c|c|}
\hline & EFBF & $\mathrm{CCF}$ & $\mathrm{PP}$ & PCL & $\mathrm{KBF}$ & $\mathrm{KCF}$ \\
\hline Moisture (\%) & $5.06 \pm 1.5^{\mathrm{a}}$ & $6.74 \pm 0.15^{\mathrm{b}}$ & $8.54 \pm 0.08^{\mathrm{d}}$ & $11.41 \pm 0.24^{\mathrm{e}}$ & $7.69 \pm 0.09^{c}$ & $8.30 \pm 0.13^{\mathrm{d}}$ \\
\hline Ash (\%) & $3.48 \pm 0.16^{\mathrm{a}}$ & $3.73 \pm 0.48^{\mathrm{a}}$ & $5.48 \pm 0.27^{\mathrm{b}}$ & $7.80 \pm 0.28^{c}$ & $7.15 \pm 0.16^{\mathrm{c}}$ & $5.10 \pm 0.16^{\mathrm{b}}$ \\
\hline Extractive (\%) & $11.51 \pm 0.02^{\mathrm{a}}$ & $18.02 \pm 0.09^{c}$ & $44.82 \pm 1.34^{\mathrm{e}}$ & $39.74 \pm 2.77^{\mathrm{d}}$ & $12.44 \pm 0.98^{\mathrm{ab}}$ & $13.03 \pm 0.24^{\mathrm{b}}$ \\
\hline \multicolumn{7}{|l|}{ Total carbohydrate (\%) } \\
\hline Cellulose (as glucan) & $34.46 \pm 0.95^{\mathrm{d}}$ & $24.58 \pm 0.30^{\mathrm{b}}$ & $13.39 \pm 0.10^{\mathrm{a}}$ & $29.08 \pm 0.05^{\mathrm{c}}$ & $49.59 \pm 4.31^{\mathrm{e}}$ & $35.21 \pm 3.11^{\mathrm{d}}$ \\
\hline Hemicellulose (as xylan) & $19.61 \pm 1.40^{\mathrm{d}}$ & $8.67 \pm 0.14^{\mathrm{b}}$ & $25.53 \pm 2.62^{\mathrm{e}}$ & $18.43 \pm 1.18^{\mathrm{d}}$ & $7.08 \pm 0.68^{\mathrm{a}}$ & $11.68 \pm 0.59^{c}$ \\
\hline \multicolumn{7}{|l|}{ Total lignin (\%) } \\
\hline Acid soluble lignin & $2.84 \pm 0.13^{b c}$ & $1.20 \pm 0.01^{\mathrm{a}}$ & $3.19 \pm 0.55^{\mathrm{c}}$ & $2.54 \pm 0.12^{\mathrm{b}}$ & $2.86 \pm 0.31^{b c}$ & $2.15 \pm 0.13^{\mathrm{b}}$ \\
\hline Klason lignin & $19.50 \pm 0.71^{\mathrm{c}}$ & $42.67 \pm 0.47^{\mathrm{e}}$ & $16.50 \pm 0.24^{\mathrm{b}}$ & $12.83 \pm 0.71^{\mathrm{a}}$ & $18.84 \pm 1.65^{\mathrm{c}}$ & $30.34 \pm 0.47^{\mathrm{d}}$ \\
\hline
\end{tabular}

(a) EFBF: palm oil empty fruit bunch fiber; CCF: coconut coir fiber; PP: pineapple peel; PCL: pineapple crown leaves; KBF: kenaf bast fiber; KCF: kenaf core fiber.

(b) a-e: the same alphabets in the same row represent that there are no significant differences between the mean values $(P>0.05)$.

medium containing $20 \mathrm{~g} \mathrm{~L}^{-1}$ maltose, $1.8 \mathrm{~g} \mathrm{~L}^{-1}$ diammonium tartrate, $0.5 \mathrm{~g} \mathrm{~L}^{-1}$ yeast extract, $0.5 \mathrm{~g} \mathrm{~L}^{-1}$ magnesium sulfate, $0.2 \mathrm{~g} \mathrm{~L}^{-1}$ dipotassium hydrogen phosphate, and $0.013 \mathrm{~g} \mathrm{~L}^{-1}$ calcium chloride. A. niger I-1472 was incubated at $30^{\circ} \mathrm{C}$ for three days at $180 \mathrm{rpm}$. After being autoclaved at $121^{\circ} \mathrm{C}$ for $15 \mathrm{~min}$, approximately $0.5 \mathrm{~mL}$ of $1 \mathrm{~g} \mathrm{~L}^{-1}$ ferulic acid solution (for experiment control) or lignocellulosic hydrolysate was added daily into the fermentation medium separately starting on day 3 and continued until day 6. Fermentation was terminated on day 7 by separating the cell pellets from the medium. The collected cell pellets were oven-dried at $105^{\circ} \mathrm{C}$ to determine the dried cell weight [20]. Vanillic acid and ferulic acid content in the medium were determined using HPLC following the protocol as described in Section 2.2.3(b).

\section{Results and Discussion}

3.1. Compositional Analysis of Different Agricultural Biomasses. The potential of an agricultural residual as a feedstock for biorefinery processes was initially predicted based on chemical composition. Therefore, compositional analysis of the six different biomasses used in this study was performed prior to any chemical treatment. Table 1 depicts the results of the compositional analysis of the different biomasses. CCF contained the highest levels of Klason lignin $(42.67 \pm 0.47 \%)$, as previously reported by [21]. As lignin is a good source of phenolic compounds, the results suggested that CCF might be the best source of phenolic compounds among the tested biomasses. In addition to lignin, the results also showed that EFBF and KBF were the reliable sources of sugars (total sugars $>50 \%$ ), and $\mathrm{KBF}$ was also a good source of glucose.

\subsection{Efficiency of Alkaline Treatment and Organosolv Treat-} ment on Delignification. In this study, the extent of delignification of six different agricultural residues by treatment with $50 \mathrm{~g} \mathrm{~L}^{-1}$ sodium hydroxide and organosolv (mixture of $50 \mathrm{~g} \mathrm{~L}^{-1}$ sodium hydroxide and $1.217 \mathrm{~g} \mathrm{~mL}^{-1}$ aqueous glycerol) was evaluated based on the total soluble lignin content in the produced black liquor. Table 2 depicts that alkaline
TABLE 2: Total soluble lignin in black liquor produced from six different biomasses through alkaline and organosolv treatment at $120^{\circ} \mathrm{C}$ for an hour $(n=3 ; P<0.05)$.

\begin{tabular}{lcc}
\hline Biomass & $\begin{array}{c}\text { Organosolv treatment } \\
\text { Soluble lignin } \\
\left(\mathrm{mg} \mathrm{g}^{-1} \text { biomass; d.b. }\right)\end{array}$ & $\begin{array}{c}\text { Alkaline treatment } \\
\text { Soluble lignin } \\
\left(\mathrm{mg} \mathrm{g}^{-1} \text { biomass; } d . b .\right)\end{array}$ \\
\hline EFBF & $255.15 \pm 28.19^{\mathrm{aD}}$ & $418.18 \pm 12.73^{\mathrm{bC}}$ \\
CCF & $373.94 \pm 29.56^{\mathrm{aE}}$ & $510.30 \pm 38.88^{\mathrm{bD}}$ \\
PP & $160.91 \pm 8.67^{\mathrm{aA}}$ & $221.82 \pm 29.97^{\mathrm{bA}}$ \\
PCL & $180.61 \pm 6.19^{\mathrm{aB}}$ & $265.76 \pm 15.89^{\mathrm{bB}}$ \\
KBF & $210.00 \pm 18.79^{\mathrm{aC}}$ & $393.64 \pm 49.17^{\mathrm{bC}}$ \\
KCF & $147.58 \pm 12.47^{\mathrm{aA}}$ & $250.00 \pm 4.04 \mathrm{~b}^{\mathrm{AB}}$ \\
\hline
\end{tabular}

(a) EFBF: palm oil empty fruit bunch fiber; CCF: coconut coir fiber; PP: pineapple peel; PCL: pineapple crown leaves; KBF: kenaf bast fiber; KCF: kenaf core fiber.

(b) a-b: different alphabets in the same row represent that there are significant differences between the mean values of the different treatments $(P<0.05)$. (c) A-E: different alphabets in the same column represent that there are significant differences between the mean values of the different biomasses $(P<0.05)$.

treatment with $50 \mathrm{~g} \mathrm{~L}^{-1}$ sodium hydroxide extracted more lignin into black liquor than organosolv treatment. This finding suggested that the extent of delignification was the highest during alkaline treatment. Thus, this treatment was initially proposed as the best treatment for the recovery of lignin and phenolic compounds from the studied biomasses. During alkaline treatment, it is possible that hydroxide anions cleaved the $\alpha$-and $\beta$-aryl ether bonds in lignin, causing the polymer to fragment into smaller water/alkaline-soluble fragments. The lignin fragmentation process continued with the cleavage of linkages holding the phenylpropane units and generated additional free phenolic hydroxyl groups. The presence of these hydroxyl groups increased the hydrophilicity of lignin and its fragments. As a result, solubility of the lignin fragments in black liquor increased during alkaline treatment [22]. However, in the organosolv treatment, lignin tends to solubilize in the organic phase. As reported by [23], delignification using a mixture of aqueous-organic solvents will effectively separate lignocellulose into three main fractions that include hemicellulose soluble in the aqueous phase, lignin, 
TABLE 3: Ferulic acid content in lignin-free liquor produced from six different biomasses through alkaline and organosolv treatment at $120^{\circ} \mathrm{C}$ for an hour $(n=3 ; P<0.05)$.

\begin{tabular}{lcccc}
\hline \multirow{2}{*}{ Biomass } & \multicolumn{2}{c}{ Concentration $\left(\mathrm{mg} \mathrm{L}^{-1}\right)$} & \multicolumn{2}{c}{ Yield $\left(\mathrm{mg} \mathrm{g}^{-1}\right.$ biomass; d.b.) } \\
& Organosolv treatment & Alkaline treatment & Organosolv treatment & Alkaline treatment \\
\hline EFB & $12.93 \pm 2.72^{\mathrm{aB}}$ & $11.53 \pm 1.88^{\mathrm{aB}}$ & $0.65 \pm 0.14^{\mathrm{aB}}$ & $0.58 \pm 0.09^{\mathrm{aB}}$ \\
CCF & $3.49 \pm 0.64^{\mathrm{aA}}$ & $3.29 \pm 0.35^{\mathrm{aA}}$ & $0.17 \pm 0.03^{\mathrm{aA}}$ & $0.16 \pm 0.02^{\mathrm{aA}}$ \\
PP & $228.83 \pm 8.96^{\mathrm{aE}}$ & $201.89 \pm 18.38^{\mathrm{aE}}$ & $5.72 \pm 0.22^{\mathrm{aD}}$ & $5.05 \pm 0.46^{\mathrm{aD}}$ \\
PCL & $123.94 \pm 16.59^{\mathrm{aD}}$ & $119.99 \pm 11.32^{\mathrm{aD}}$ & $3.10 \pm 0.42^{\mathrm{aC}}$ & $3.00 \pm 0.28^{\mathrm{aC}}$ \\
KBF & $2.80 \pm 0.93^{\mathrm{aA}}$ & $2.92 \pm 0.39^{\mathrm{aA}}$ & $0.14 \pm 0.05^{\mathrm{aA}}$ & $0.15 \pm 0.02^{\mathrm{aA}}$ \\
KCF & $30.98 \pm 1.81^{\mathrm{aC}}$ & $30.18 \pm 1.99^{\mathrm{aC}}$ & $0.78 \pm 0.05^{\mathrm{aB}}$ & $0.76 \pm 0.05^{\mathrm{aB}}$ \\
\hline
\end{tabular}

(a) EFBF: palm oil empty fruit bunch fiber; CCF: coconut coir fiber; PP: pineapple peel; PCL: pineapple crown leaves; KBF: kenaf bast fiber; KCF: kenaf core fiber.

(b) a: the same alphabets in the same row represent that there are no significant differences between the mean values of the different treatments $(P>0.05)$.

(c) A-E: different alphabets in the same column represent that there are significant differences between the mean values of the different biomasses $(P<0.05)$.

which is soluble in the organic phase, and cellulose, which will remain intact as a solid. A study by [24] showed that glycerol acted more selectively on lignin, and lignin solubilization was proportional to glycerol concentration. However, lignin solubilization was also reported by [24] to be affected by the chemical used in assisting aqueous glycerol treatment. At higher glycerol concentration, an acid-catalyzed treatment was reported to contribute to higher lignin solubilization compared to alkaline-catalyzed treatment. Therefore, the improved performance of alkaline treatment compared to organosolv treatment in delignification obtained in this study is reasonable.

The results in Table 2 also showed that the highest amount of lignin was extracted from CCF compared to the other tested biomasses. Therefore, CCF was proven to be a good source of the lignin polymer. This finding is expected because, from this study, CCF had been found to contain large quantities of lignin content $(42.67 \pm 0.47 \%)$. For an optimum biorefinery process, all three main components from lignocellulose, namely, cellulose, hemicellulose, and lignin, must be recovered. Many studies have focused on technology to maximize the sugar recovery from cellulose and hemicellulose $[25,26]$, but less attention has been paid to the recovery of lignin and other phenolic compounds from black liquor. As reported by [5], lignin and carbohydrate molecular conformation can be affected by the $\mathrm{pH}$ environment of black liquor. At high alkalinity, phenol groups are ionized, and lignin molecules become soluble to form compact and spherical structures. As the $\mathrm{pH}$ decreased, lignin molecules start to dissociate, forming shapeless and voluminous structures. Therefore, in an acidic environment, lignin precipitation was observed [18]. The successful separation of lignin precipitate from black liquor will produce clear brownish liquor containing mainly carbohydrate fragments and phenolic compounds. Following the recovery of ligninfree liquor, the total phenolic content, specifically the ferulic acid content, was studied. Additionally, studies on recovered lignin fragments must be conducted for the exploitation of more phenolic compounds in future research.

3.3. Ferulic Acid in Lignin-Free Liquor from Alkaline and Organosolv Treatment. The ferulic acid yield from different biomasses after alkaline and organosolv treatment is depicted in Table 3. The ferulic acid yield from alkaline treatment was not significantly different $(P<0.05)$ from organosolv treatment. The liberation of ferulic acid from the lignin/phenolic-carbohydrate complex is dependent on the cleavage of ester bonds and ether bonds in the complex. Ester bonds linking ferulic acid to hemicellulose can be easily cleaved in alkaline conditions [11]. Because both treatments were performed under alkaline conditions, the intensity of ferulic acid liberation from the lignin/phenolic-hemicellulose structure was similar. As reported in study [26], aqueous glycerol treatment at $120^{\circ} \mathrm{C}$ without alkali catalyst does not exert any significant effect on EFBF. Similarly, results reported in this study showed that, even with the presence of alkaline, organosolv treatment at low temperature $\left(120^{\circ} \mathrm{C}\right)$ is still unable to improve the ferulic acid yield. The results suggested that the presence of glycerol did not have any significant effect on the release of ferulic acid at lower treatment temperature. Furthermore, PP was the best source of ferulic acid (5.72 \pm $\left.0.22 \mathrm{mg} \mathrm{g}^{-1} \mathrm{PP}\right)$, followed by PCL $\left(3.10 \pm 0.42 \mathrm{mg} \mathrm{g}^{-1} \mathrm{PCL}\right)$. According to [27], ferulic acid was found to be the most abundant hydroxycinnamic acid in the pineapple cell wall, where it was esterified to hemicellulose, similar to the other herbaceous crops. Thus, from the current samples, PP was the most promising agricultural residue as a ferulic acid source.

\subsection{Efficiency of Alkaline and Organosolv Treatment for Total} Phenolic Compounds Extraction. Lignin is the main source of aromatic compounds from the fractionation of lignocellulose. Lignin extraction by different fractionation processes will yield lignin fragment with different physicochemical properties. Various phenolic compounds have been shown to form lignin-carbohydrate structures. The major phenolic compounds identified in the complex were cinnamic acids such as ferulic acid $[6,11]$. As different linkages will be cleaved under different delignification environment, it was believed that phenolic compounds other than ferulic acid will also be liberated from the different treatments. Table 4 shows the content of total phenolic compounds and nonferulate phenolic compounds (NFPC) in lignin-free liquor after alkaline or organosolv treatment. The organosolv treatment was superior to alkaline treatment in the liberation of phenolic compounds from the lignin/phenolic-carbohydrate complex in the samples. As reported by [28], organosolv methods 
TABLE 4: Total nonferulate phenolic compounds (NFPC) and percentage of ferulic acid (FA) content in total phenolic compounds (TPC) in lignin-free liquor produced from six different biomasses through alkaline and organosolv treatment at $120^{\circ} \mathrm{C}$ for an hour $(n=3 ; P<0.05)$.

\begin{tabular}{|c|c|c|c|c|c|c|}
\hline \multirow{2}{*}{ Biomass } & \multicolumn{2}{|c|}{ TPC (mg GAE g ${ }^{-1}$ biomass; $\left.d . b.\right)$} & \multicolumn{2}{|c|}{ NFPC (mg GAE g ${ }^{-1}$ biomass; d.b.) } & \multicolumn{2}{|c|}{$\%$ FA of TPC } \\
\hline & Organosolv treatment & Alkaline treatment & Organosolv treatment & Alkaline treatment & Organosolv treatment & Alkaline treatment \\
\hline EFB & $9.44 \pm 0.70^{\mathrm{bA}}$ & $8.94 \pm 0.13^{\mathrm{bA}}$ & $7.60 \pm 0.74^{\mathrm{bA}}$ & $7.12 \pm 0.10^{\mathrm{bA}}$ & $19.62 \pm 1.90^{\mathrm{dA}}$ & $20.39 \pm 0.10^{\mathrm{dA}}$ \\
\hline CCF & $47.99 \pm 4.13^{\mathrm{eA}}$ & $27.169 \pm 2.65^{\mathrm{dB}}$ & $46.29 \pm 4.14^{\mathrm{eA}}$ & $25.47 \pm 2.65^{\mathrm{dB}}$ & $3.57 \pm 0.31^{\mathrm{aB}}$ & $6.30 \pm 0.65^{\mathrm{aA}}$ \\
\hline PP & $27.17 \pm 1.90^{\mathrm{dA}}$ & $20.73 \pm 0.53^{\mathrm{cB}}$ & $24.63 \pm 1.87^{\mathrm{dA}}$ & $18.39 \pm 0.60^{\mathrm{cB}}$ & $9.38 \pm 0.57^{\mathrm{bB}}$ & $11.29 \pm 0.84^{\mathrm{bA}}$ \\
\hline PCL & $21.78 \pm 0.80^{\mathrm{cA}}$ & $18.23 \pm 2.23^{\mathrm{cB}}$ & $18.31 \pm 3.01^{\mathrm{cA}}$ & $16.50 \pm 2.30^{\mathrm{cA}}$ & $8.89 \pm 1.54^{\mathrm{bA}}$ & $9.59 \pm 1.51^{\mathrm{bA}}$ \\
\hline $\mathrm{KBF}$ & $5.56 \pm 0.35^{\mathrm{aA}}$ & $3.61 \pm 0.09^{\mathrm{aB}}$ & $3.86 \pm 0.37^{\mathrm{aA}}$ & $1.92 \pm 0.08^{\mathrm{aB}}$ & $30.63 \pm 2.19^{\mathrm{eB}}$ & $67.34 \pm 0.92^{\mathrm{eA}}$ \\
\hline KCF & $8.19 \pm 0.69^{\mathrm{bA}}$ & $7.04 \pm 0.13^{\mathrm{bA}}$ & $7.13 \pm 0.68^{\mathrm{bA}}$ & $5.99 \pm 0.14^{\mathrm{bB}}$ & $12.96 \pm 1.00^{\mathrm{cB}}$ & $14.93 \pm 0.43^{\mathrm{cA}}$ \\
\hline
\end{tabular}

(a) EFBF: palm oil empty fruit bunch fiber; CCF: coconut coir fiber; PP: pineapple peel; PCL: pineapple crown leaves; KBF: kenaf bast fiber; KCF: kenaf core fiber.

(b) GAE represents gallic acid equivalent.

(c) a-e: different alphabets in the same column represent that there are significant differences between the mean values of the different biomasses $(P<0.05)$.

(d) A-B: different alphabets in the same row represent that there are significant differences between the mean values of the different treatments $(P<0.05)$.

give rise to the production of low molecular weight lignin with relatively high amounts of phenolic hydroxyl groups and oxidized groups. Thus, organosolv treatment was believed to be able to yield more free phenolic compounds from lignin fragmentation compared to alkaline treatment.

Among the tested biomasses, it was found that the largest amounts of phenolic compounds $(47.99 \pm 4.13 \mathrm{mg}$ gallic acid equivalent $\mathrm{g}^{-1} \mathrm{CCF}$ ) were successfully extracted from CCF. This result can be correlated with the amount of lignin contained in the CCF. According to [28], coconut coir fiber was reported to be one of the natural fibers containing the highest lignin content (average of 46\%). Results from the compositional analysis in this study also supported this finding, in which CCF was found to contain $42.67 \pm 0.47 \%$ Klason lignin. Although organosolv treatment was more effective than alkaline treatment for the extraction of phenolic compounds, its performance in ferulic acid extraction from the samples (Table 3) was not significantly different $(P<$ 0.05). Therefore, the percentage of ferulic acid in the total phenolic compounds from organosolv treatment was lower than that from alkaline treatment because the organosolv treatment yielded more nonferulate phenolic compounds. However, overall, the percentage of ferulic acid in the total phenolic compounds in the liquor from all tested samples was still considered low. These results suggested that the extent of ferulic acid liberation from lignin/phenolic-carbohydrate structures was lower than other phenolic compounds. As reported in the review by [11], alkali cleaves the ester linkage and releases a small amount of ferulic acid from carbohydrates, although acid is expected to cleave the ether bonds between the ferulic acid and lignin. This explained why ferulic acid liberation in the alkaline treatments was low. Due to the high yield of nonferulate phenolic compounds in black liquor, the potential use of these phenolic compounds should be further explored, as previously published studies have shown the antioxidant properties of phenolic compounds present in black liquor obtained from different biomasses [29].

3.5. Cell Growth and Vanillic Acid Yield from A. niger I-1472 Fermentation of Lignin-Free Liquor. Table 5 depicts the cell growth and vanillic acid production from the fermentation of lignin-free liquor by A. niger I-1472. The experimental blank showed that the fermentation medium used in this study supported $A$. niger growth at $9.13 \pm 0.8 \mathrm{~g}$ dry cell $\mathrm{L}^{-1}$. For the experimental control, which was fed $1 \mathrm{~g} \mathrm{~L}^{-1}$ ferulic acid solution, the production of $2.74 \pm 0.28 \mathrm{mg} \mathrm{L}^{-1}$ vanillic acid was observed after the total feeding of $2 \mathrm{mg}$ ferulic acid over seven days of fermentation. In addition, there was no residual ferulic acid in the control medium after fermentation. This finding suggested that $A$. niger completely utilized the ferulic acid provided. However, the utilization of ferulic acid did not contribute to additional cell growth. The results from dry cell weight analysis showed that there were no significant differences $(P>0.05)$ between cell growth in the blank medium and the control medium. Based on the results of the growth study (growth curve not shown), A. niger entered its stationary phase at day 4. In this study, vanillic acid was produced by $A$. niger after ferulic acid feeding before the stationary phase began (started at day 3 ). Therefore, vanillic acid production without extra cell growth in the control medium suggested that the conversion of ferulic acid into vanillic acid by $A$. niger occurred during the stationary phase. The molar conversion of ferulic acid into vanillic acid by $A$. niger under the fermentation conditions in this study was found to be approximately $4.75 \%$. According to study [30], molar conversion of ferulic acid into vanillic acid by $A$. niger under optimum fermentation condition achieved $88 \%$. Our experiment control only achieved a lower conversion level compared to the previous reported study. In the reported study, a total of $1200 \mathrm{mg}$ ferulic acid was fed to yield $920 \mathrm{mg}$ vanillic acid. As the ferulic acid level in the liquor of biomasses was low, fermentation control of this study was also fed with lower amount of ferulic acid. Thus, lower amount of ferulic acid feeding was believed be the factor that contributes to the low molar conversion by $A$. niger.

Among the produced liquors, it was found that only liquor produced from PP and PCL was able to undergo fermentation. The liquor from PP and PCL obtained by organosolv treatment produced approximately $1.21 \pm 0.20 \mathrm{mg} \mathrm{L}^{-1}$ 
TABLE 5: Cell growth (based on dry cell weight) and vanillic acid yield from fermentation Aspergillus niger I-1472 on lignin-free liquor produced from six different biomasses through alkaline and organosolv treatment at $120^{\circ} \mathrm{C}$ for an hour $(n=3 ; P<0.05)$.

\begin{tabular}{lcccc}
\hline Biomass & \multicolumn{2}{c}{ Organosolv treatment } & \multicolumn{2}{c}{ Alkaline treatment } \\
Cell growth (dry cell weight $)$ & $\begin{array}{c}\text { Vanillic acid yield } \\
\left(\mathrm{g} \mathrm{L}^{-1}\right)\end{array}$ & $\begin{array}{c}\text { Cell growth (dry cell weight }) \\
\left(\mathrm{g} \mathrm{L}^{-1}\right)\end{array}$ & $\begin{array}{c}\text { Vanillic acid yield } \\
\left(\mathrm{mg} \mathrm{L}^{-1}\right)\end{array}$ \\
\hline Blank & $9.13 \pm 0.8$ & n.d & & \\
Control & $8.40 \pm 0.5$ & $2.74 \pm 0.28$ & $11.17 \pm 1.43$ & n.d \\
EFB & $15.57 \pm 2.07$ & n.d & $11.67 \pm 0.40$ & n.d \\
CCF & $13.33 \pm 0.80$ & n.d & $11.57 \pm 1.33$ & $1.05 \pm 0.05$ \\
PP & $12.93 \pm 0.30$ & $1.21 \pm 0.20$ & $11.77 \pm 0.50$ & $0.53 \pm 0.11$ \\
PCL & $14.90 \pm 0.27$ & $0.82 \pm 0.02$ & $12.00 \pm 1.27$ & n.d \\
KB & $14.77 \pm 2.27$ & n.d & $11.80 \pm 1.00$ & n.d \\
KC & $15.53 \pm 0.60$ & n.d & \\
\hline
\end{tabular}

(a) EFBF: palm oil empty fruit bunch fiber; CCF: coconut coir fiber; PP: pineapple peel; PCL: pineapple crown leaves; KBF: kenaf bast fiber; KCF: kenaf core fiber.

(b) n.d means not detected.

and $0.82 \pm 0.02 \mathrm{mg} \mathrm{L}^{-1}$ vanillic acid, respectively, whereas $1.05 \pm 0.05 \mathrm{mg} \mathrm{L}^{-1}$ and $0.53 \pm 0.11 \mathrm{mg} \mathrm{L}^{-1}$ vanillic acid were produced from PP and PCL liquor obtained by alkaline treatment, respectively. The failure of $A$. niger to convert ferulic acid into the liquors obtained from EFBF, CCF, $\mathrm{KBF}$, and KCF might be due to the very low ferulic acid content within. Although the total phenolic compounds in the lignocellulosic liquor were high (as reported in Section 3.4), the liquors failed to support the growth of $A$. niger and subsequent conversion into vanillic acid. Ferulic acid conversion in liquors from PP and PCL was higher than the experimental control. Approximately 9.07\% and 9.13\% of molar conversion were observed for the fermentation of PP liquor obtained from organosolv treatment and alkaline treatment, respectively, whereas $11.67 \%$ and $7.69 \%$ of molar conversion were observed for the fermentation of PCL liquor obtained from organosolv treatment and alkaline treatment, respectively. A higher conversion rate of ferulic acid into vanillic acid by $A$. niger appeared to be associated with cell growth during fermentation. Cell growth was observed with the increased feeding of lignocellulosic liquor. This finding was supported by the results of total sugar analysis (data not shown), in which the presence of carbohydrates (total sugar content) in the liquor becomes the additional carbon source for $A$. niger growth. The results in Table 5 also showed that cell growth after the feeding of lignocellulosic liquors obtained from organosolv treatment was higher than feeding with liquors obtained from alkaline treatment. Increased cell growth after the feeding of glycerol-containing liquor was believed to be due to the ability of $A$. niger to utilize glycerol [31].

\section{Conclusion}

Among the tested agricultural residues, it was found that PP was the best source of ferulic acid, whereas CCF was the best source of phenolic compounds. The data from this study also proved that alkaline treatment was more efficient than organosolv treatment in the delignification of lignocellulosic biomass. The ferulic acid yield from PP and PCL was successfully converted into vanillic acid by A. niger I-1472. Approximately $1.21 \pm 0.20 \mathrm{mg} \mathrm{L}^{-1}$ and $1.05 \pm 0.05 \mathrm{mg} \mathrm{L}^{-1}$ vanillic acid were produced from PP liquor after organosolv treatment or alkaline treatment, respectively, whereas $0.82 \pm 0.02 \mathrm{mg} \mathrm{L}^{-1}$ and $0.53 \pm 0.11 \mathrm{mg} \mathrm{L}^{-1}$ vanillic acid were produced from PCL liquor after organosolv treatment or alkaline treatment, respectively.

\section{Conflict of Interests}

The authors declare that there is no conflict of interests regarding the publication of this paper.

\section{Acknowledgments}

The authors express their deepest appreciation to Universiti Kebangsaan Malaysia for the financial support provided for conducting this research under the Grant scheme with Project code no. DIP-2012-018.

\section{References}

[1] C. S. Goh, K. T. Tan, K. T. Lee, and S. Bhatia, "Bio-ethanol from lignocellulose: Status, perspectives and challenges in Malaysia," Bioresource Technology, vol. 101, no. 13, pp. 4834-4841, 2010.

[2] Y.-H. P. Zhang, "Reviving the carbohydrate economy via multi-product lignocellulose biorefineries," Journal of Industrial Microbiology and Biotechnology, vol. 35, no. 5, pp. 367-375, 2008.

[3] V. B. Agbor, N. Cicek, R. Sparling, A. Berlin, and D. B. Levin, "Biomass pretreatment: fundamentals toward application," Biotechnology Advances, vol. 29, no. 6, pp. 675-685, 2011.

[4] O. Hassan, T. P. Ling, M. Y. Maskat et al., "Optimization of pretreatments for the hydrolysis of oil palm empty fruit bunch fiber (EFBF) using enzyme mixtures," Biomass and Bioenergy, vol. 56, pp. 137-146, 2013.

[5] M. Cardoso, É. D. de Oliveira, and M. L. Passos, "Chemical composition and physical properties of black liquors and their effects on liquor recovery operation in Brazilian pulp mills," Fuel, vol. 88, no. 4, pp. 756-763, 2009. 
[6] P. Torre, B. Aliakbarian, B. Rivas, J. M. Domínguez, and A. Converti, "Release of ferulic acid from corn cobs by alkaline hydrolysis," Biochemical Engineering Journal, vol. 40, no. 3, pp. 500-506, 2008

[7] B. R. Torres, B. Aliakbarian, P. Torre et al., "Vanillin bioproduction from alkaline hydrolyzate of corn cob by Escherichia coli JM109/pBB1," Enzyme and Microbial Technology, vol. 44, no. 3, pp. 154-158, 2009.

[8] L. Zheng, P. Zheng, Z. Sun, Y. Bai, J. Wang, and X. Guo, "Production of vanillin from waste residue of rice bran oil by Aspergillus niger and Pycnoporus cinnabarinus," Bioresource Technology, vol. 98, no. 5, pp. 1115-1119, 2007.

[9] S. Mathew and T. E. Abraham, "Bioconversions of ferulic acid, an hydroxycinnamic acid," Critical Reviews in Microbiology, vol. 32, no. 3, pp. 115-125, 2006.

[10] A. U. Buranov and G. Mazza, "Lignin in straw of herbaceous crops," Industrial Crops and Products, vol. 28, no. 3, pp. 237-259, 2008.

[11] A. U. Buranov and G. Mazza, "Extraction and purification of ferulic acid from flax shives, wheat and corn bran by alkaline hydrolysis and pressurised solvents," Food Chemistry, vol. 115, no. 4, pp. 1542-1548, 2009.

[12] S. Ghosh, A. Sachan, S. K. Sen, and A. Mitra, "Microbial transformation of ferulic acid to vanillic acid by Streptomyces sannanensis MTCC 6637," Journal of Industrial Microbiology and Biotechnology, vol. 34, no. 2, pp. 131-138, 2007.

[13] A. Sluiter, B. Hames, R. Ruiz et al., "Determination of structural carbohydrates and lignin in biomass," Technical Report NREL/TP-510-42618, Laboratory Analytical Procedures (LAP) National Renewable Energy Laboratory (NREL), 2005, http:// www.nrel.gov/biomass/pdfs/42618.pdf.

[14] A. Sluiter, B. Hames, R. Ruiz, C. Scarlata, J. Sluiter, and D. Templeton, "Determine of ash in biomass," Laboratory Analytical Procedures (LAP), National Renewable Energy Laboratory (NREL), 2005, http://www.nrel.gov/biomass/pdfs/42622.pdf.

[15] A. Sluiter, R. Ruiz, C. Scarlata, J. Sluiter, and D. Templeton, "Determination of extractives in biomass," Laboratory Analytical Procedure (LAP) National Renewable Energy Laboratory (NREL), 2008, http://www.nrel.gov/biomass/pdfs/42619.pdf.

[16] E. Tina, Determination of Acid Soluble Lignin in Biomass, Laboratory Analytical Procedure (LAP), National Renewable Energy Laboratory (NREL), 1996, http://infohouse.p2ric.org/ref/40/ 39121.pdf.

[17] A. L. Mayra, J. Antonio, M. Rodriguez et al., "Black liquor lignin degradation by Trametes elegans," International Biodeterioration \& Biodegradation, vol. 52, pp. 167-173, 2004.

[18] R. Sun, J. Tomkinson, and J. Bolton, "Effects of precipitation $\mathrm{pH}$ on the physico-chemical properties of the lignins isolated from the black liquor of oil palm empty fruit bunch fibre pulping," Polymer Degradation and Stability, vol. 63, no. 2, pp. 195-200, 1999.

[19] K. R. Praveen and B. Awang, "Antioxidant activity, total phenolic and flavonoid content of Morinda citrifolia fruit extracts from various extraction processes," Journal of Engineering Science and Technology, vol. 2, pp. 70-80, 2007.

[20] C. Stentelaire, L. Lesage-Meessen, J. Oddou et al., "Design of a fungal bioprocess for vanillin production from vanillic acid at scalable level by Pycnoporus cinnabarinus," Journal of Bioscience and Bioengineering, vol. 89, no. 3, pp. 223-230, 2000.

[21] A. Majid, "Coconut fiber: a versatile materials and its applications in engineering," Journal of Civil Engineering and Construction Technology, vol. 2, pp. 189-197, 2011.
[22] F. S. Chakar and A. J. Ragauskas, "Review of current and future softwood kraft lignin process chemistry," Industrial Crops and Products, vol. 20, no. 2, pp. 131-141, 2004.

[23] A. Demirbas, "Aqueous glycerol delignification of wood chips and ground wood," Bioresource Technology, vol. 63, no. 2, pp. 179-185, 1998.

[24] C. Martín, J. Puls, B. Saake, and A. Schreiber, "Effect of glycerol preatreatment on component recovery and enzymatic hydrolysis of sugarcane bagasse," Cellulose Chemistry and Technology, vol. 45, no. 7-8, pp. 487-494, 2011.

[25] P. Sannigrahi, S. J. Miller, and A. J. Ragauskas, "Effects of organosolv pretreatment and enzymatic hydrolysis on cellulose structure and crystallinity in Loblolly pine," Carbohydrate Research, vol. 345, no. 7, pp. 965-970, 2010.

[26] T. P. Ling, O. Hassan, K. Badri, M. Y. Maskat, and W. A. W. Mustapha, "Sugar recovery of enzymatic hydrolysed oil palm empty fruit bunch fiber by chemical pretreatment," Cellulose, vol. 20, no. 6, pp. 3191-3203, 2013.

[27] B. G. Smith and P. J. Harris, "Ferulic acid is esterified to glucuronoarabinoxylans in pineapple cell walls," Phytochemistry, vol. 56, no. 5, pp. 513-519, 2001.

[28] P. Muensri, T. Kunanopparat, P. Menut, and S. Siriwattanayotin, "Effect of lignin removal on the properties of coconut coir fiber/wheat gluten biocomposite," Composites A: Applied Science and Manufacturing, vol. 42, no. 2, pp. 173-179, 2011.

[29] A. A. Elzaawely and S. Tawata, "Antioxidant activity of phenolic rich fraction obtained from Convolvulus arvensis L. Leaves grown in Egypt," Asian Journal of Crop Science, vol. 4, no. 1, pp. 32-40, 2012.

[30] L. Lesage-Meessen, M. Delattre, M. Haon et al., "A two-step bioconversion process for vanillin production from ferulic acid combining Aspergillus niger and Pycnoporus cinnabarinus," Journal of Biotechnology, vol. 50, no. 2-3, pp. 107-113, 1996.

[31] K. Rumbold, H. J. J. van Buijsen, V. M. Gray et al., "Microbial renewable feedstock utilization: a substrate-oriented approach," Bioengineered Bugs, vol. 1, no. 5, pp. 359-366, 2010. 

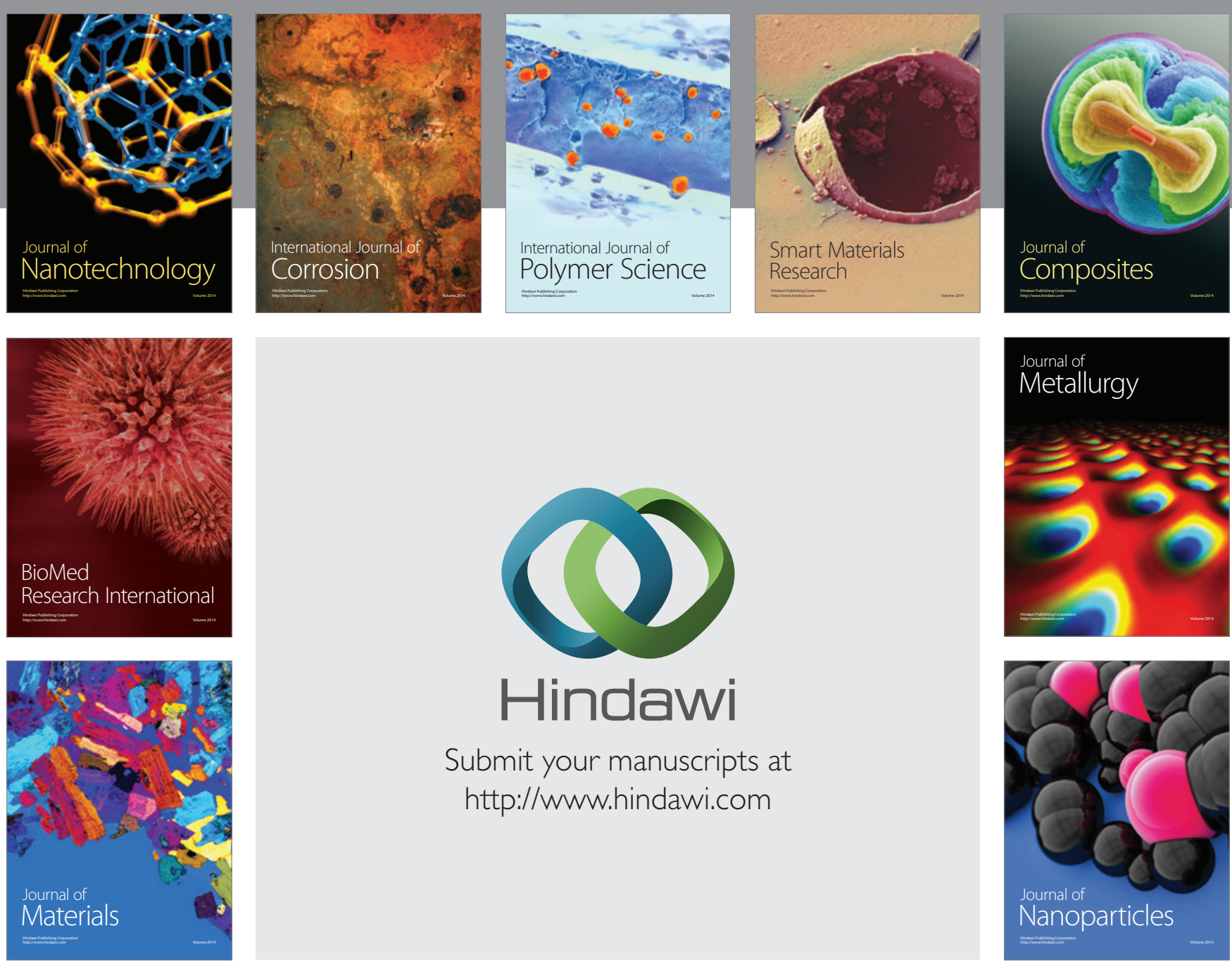

Submit your manuscripts at http://www.hindawi.com
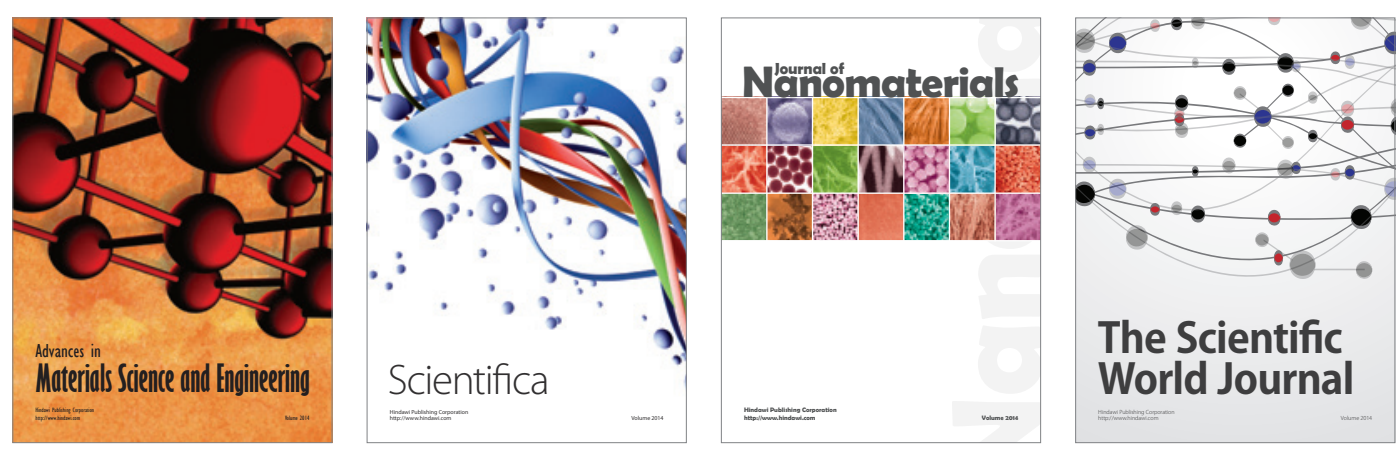

\section{The Scientific World Journal}
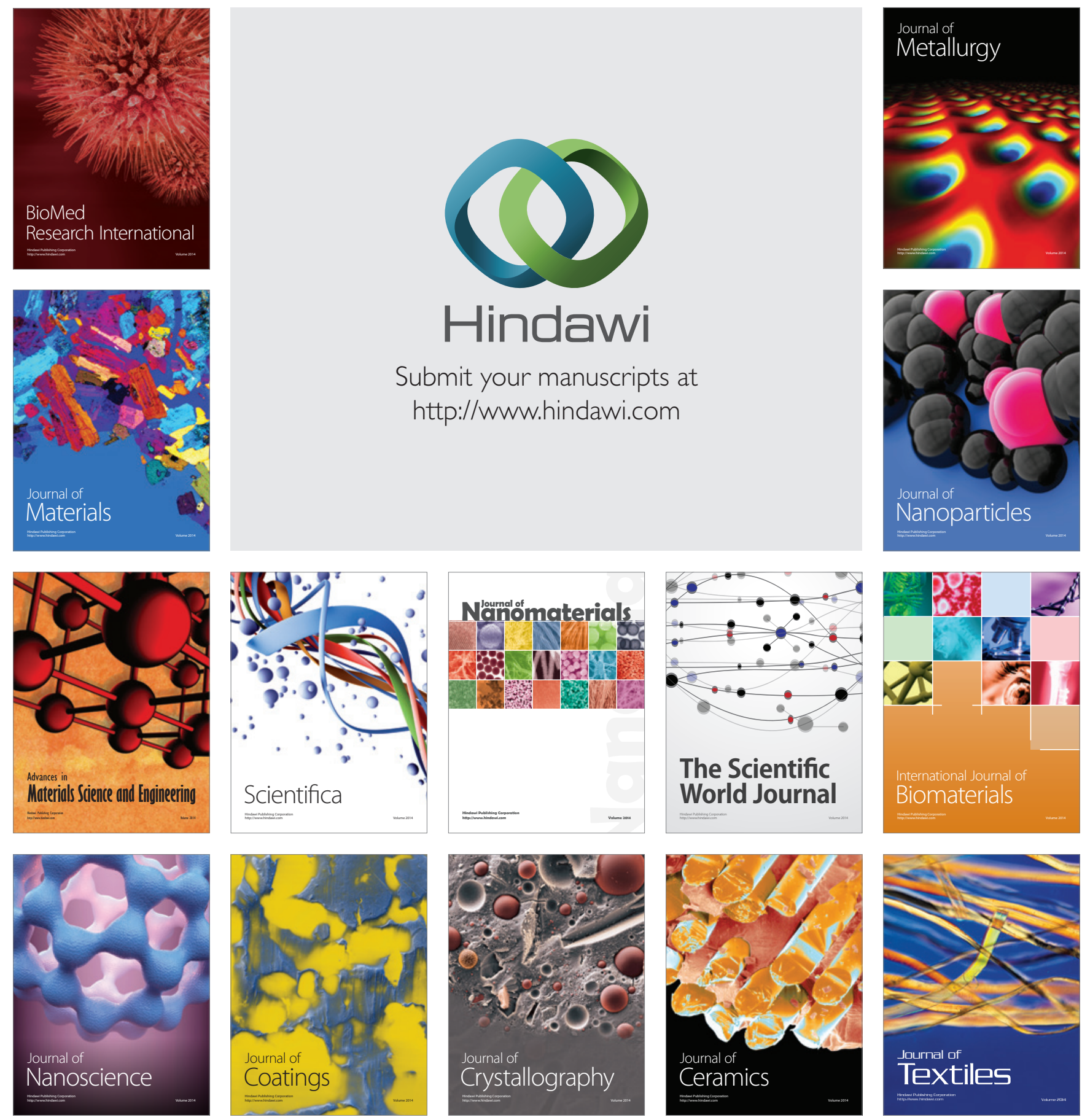